\title{
O Departamento de História da USP e as histórias que por ali caminham
}

Letícia Oliver Fernandes

Matheus de Paula Silva

Pedro José de Carvalho Neto

DOI: 10.11606/issn.2318-8855.v9i2p05-13 


\section{editorial|}

O Departamento de História da USP e as histórias que por ali caminham

Neste dossiê, os leitores e leitoras encontrarão um conjunto de dez entrevistas de profissionais que, em algum momento de suas trajetórias, passaram pelo Departamento de História da Universidade de São Paulo. Poderão transitar pelas experiências de documentalistas, professores e professoras de escola pública e particular, museólogos, editores e autores de livros didáticos - aglutinadas com o objetivo original de apresentar aos alunos e alunas da graduação em História possibilidades diversas de carreira.

Em alguma medida, a proposta apareceu também como uma resposta a angústias que nós mesmos, estudantes, tínhamos. Como funciona o cotidiano de uma documentalista? Qual o melhor caminho para entrar no mundo editorial? O que faz uma museóloga? O que um professor diria que é necessário saber antes de entrar em sala de aula?

Nossa preocupação estava em conhecer histórias que extrapolassem o ambiente acadêmico. Assim, ser um guia de possíveis caminhos profissionais, com informações e conteúdos elucidativos para jovens historiadores e historiadoras, era no que a proposta inicialmente consistia. Mas como o olhar experiente deve antecipar, as respostas a tais questões não eram simples e nem tão objetivas quanto imaginávamos - e assim o projeto, pelo próprio ato de ser colocado em processo, se transformou.

\section{O processo}

Nosso percurso começou em agosto de 2019, quando convidamos a professora Marlene Suano para nossa tradicional entrevista de trajetória acadêmica com grandes nomes da historiografia brasileira. Por motivos pessoais, a professora negou nosso convite, mas apresentou a sugestão de entrevistarmos ex-alunas e ex-alunos do De- 


\section{editorial|}

Letícia Oliver Fernandes

Matheus de Paula Silva

Pedro José de Carvalho Neto

partamento para que pudéssemos conhecer suas passagens pela USP e suas escolhas profissionais. Em nossa reunião ordinária, discutimos a proposta e decidimos que o melhor formato seria o de um dossiê de entrevistas focado nos ofícios do profissional de História. Além do tema inicial, com a ajuda da professora, chegamos a nossos primeiros nomes: Bruno Fiuza, editor de livros acadêmicos, e Carlos Ogawa, editor de livros didáticos.

E assim demos início ao projeto, com as primeiras entrevistas realizadas no final de outubro e início de novembro de 2019. Nos meses seguintes, fizemos alguns convites, mas focamos em finalizar a edição que seria lançada em março de 2020. Quando nos demos conta, já era impossível realizar entrevistas presenciais por conta da pandemia de Covid-19. Na espera pela melhora da situação - que imaginávamos que chegaria ao fim em dois ou três meses - ficamos estagnados. Com a passagem do tempo e a manutenção do estado de crise, tomamos a decisão de adaptar o dossiê para a nova realidade de isolamento social, isto é, adotar a prática de realização de entrevistas online.

Deste modo, entre abril e maio de 2020, realizamos quatro entrevistas com Alexandre de Almeida e Silvana Goulart, sobre o mundo dos arquivos; e com Fernando Ferreira e Diógenes de Castro, professores de história nas redes particular e pública, respectivamente. A experiência da entrevista online, ainda que no nosso caso tenha sido bem sucedida, tem seus "poréns": os problemas técnicos de conexão, como um dado mais óbvio; mas, também, o perigo da impessoalidade trazida pela distância física e do cansaço de ficar um punhado de horas na frente do computador após um dia de trabalho no mesmo formato. Nesse sentido, nossos entrevistados e 


\section{editorial |}

O Departamento de História da USP e as histórias que por ali caminham

entrevistadas nos ajudaram exemplarmente, enfrentando tais condições adversas sempre de maneira muito cordial e amigável.

A virada para o segundo semestre de 2020 significou uma mudança no corpo editorial da Revista, com a saída iminente de alguns membros recém-formados e a entrada de novos membros em diversos momentos da graduação. Este processo se refletiu na feitura do dossiê na medida em que, por um lado, os membros que estavam de saída puderam refletir sobre as angústias trazidas pelo fim da graduação; por outro, os membros recém-chegados puderam trazer o frescor de quem ainda tem dúvidas sobre os caminhos a seguir. Cada um dos idealizadores do dossiê pôde manifestar seus anseios, subjetividades e preferências nas discussões realizadas sobre os rumos a tomar.

Mudamos, também, ao nos questionarmos sobre quais histórias estávamos contando e que no dossiê que existia até então havia lacunas que gritavam. Das seis entrevistas realizadas, havia somente uma mulher e somente um homem negro. Respeitadas as trajetórias que havíamos conhecido, nos perguntamos sobre o quão representativas elas poderiam ser daquele conjunto tão diverso que vemos passar pelos corredores do Departamento de História. A partir disso, entramos em longas discussões sobre como poderíamos incluir outras experiências, tanto relativas a outras profissões que até então não haviam sido contempladas, quanto relativas a perspectivas distintas de gênero, raça e classe. Se, como futuros historiadores, somos leitores críticos da sociedade e das estruturas que a permeiam, como pudemos incorrer na ausência da discussão consciente sobre gênero, raça e classe?

Assim, entramos na segunda fase do projeto, em que buscamos diversificar as vozes ouvidas. Estas novas experiências trouxeram novos olhares a respeito de possíveis trajetórias profissionais, e nos relembraram de como aspectos como a classe, a identidade racial e de gênero dos sujeitos podem afetá-las diretamente, positiva ou 


\section{editorial}

Letícia Oliver Fernandes

Matheus de Paula Silva

Pedro José de Carvalho Neto

negativamente. Daí que contamos com a colaboração de Carolinne Mendes, Iracema Alvarenga, Viviane Longo e Otávio Balaguer - a primeira professora da EJA e autora de livros didáticos, a segunda professora do ensino público e os dois últimos, profissionais da área dos museus.

Ainda que tenhamos reformulado o projeto levando em consideração a necessidade de contemplar múltiplas trajetórias, sabemos que há muitas histórias que ficaram de fora, as quais decerto trariam outras experiências profissionais vividas a partir de diferentes perspectivas de gênero, sexualidade, raça e classe. Algo que a constante discussão sobre o produto final nos trouxe foi, mais do que o aguçar dos olhares para estas questões, um aprendizado sobre como trazer tais questões no processo de seleção, conversa, transcrição e revisão de cada uma das entrevistas.

Assim, entre outubro de 2019 e setembro de 2020, realizamos um total de dez entrevistas. Foi um longo trabalho, cansativo, permeado por idas e vindas e longas discussões, mas que só foi possível por seu caráter colaborativo, por nove pessoas que colocaram as mãos na massa. Podemos dividir o trabalho conjunto por trás dessas entrevistas em quatro grandes momentos: a elaboração das perguntas e a entrevista, a transcrição e revisão, a devolutiva e a revisão final.

No primeiro momento, elaboramos questões que, de certa forma, atravessaram todas as entrevistas e conferiam coesão ao conjunto. Ao mesmo tempo, sempre nos preocupamos em elaborar novas questões a partir dos diferentes currículos e ofícios, buscando contemplar as particularidades de cada pessoa. Com esse roteiro semiestruturado em mãos ou na tela do computador, fizemos entrevistas de cerca de duas horas, contando com a participação de dois ou três membros da equipe. Já nes- 


\section{editorial|}

O Departamento de História da USP e as histórias que por ali caminham

se momento, a experiência da entrevista, pelo modo como concebemos as perguntas, não se conformou ao "manual dos ofícios" inicialmente concebido.

O momento seguinte foi a transcrição. A tarefa foi dividida, preferencialmente, entre os membros que participaram da entrevista. Nessa passagem do oral para o escrito, a nossa preocupação foi conseguir manter a personalidade de cada entrevistado no texto, juntamente com o tom descontraído das nossas conversas. Ao fim de cada transcrição, pelo menos dois membros fizeram a revisão do texto para que pudéssemos enviar ao entrevistado.

A revisão foi uma etapa central para o processo como um todo, pois foi a ocasião de nos perguntarmos: qual foi o tom de cada entrevista? A partir dessa difícil resposta, pudemos, através de discussões coletivas nos documentos de textos, decidir o que seria mantido no texto final. A devolutiva representava o primeiro retorno do texto ao entrevistado e uma ponderação importante sobre como seria a construção do texto na colaboração entre as duas partes. Conferimos, desde o início, ampla liberdade para que os entrevistados modificassem os textos, fazendo cortes e adições, de modo que o resultado final fosse o mais próximo de como gostariam de ter narrado suas histórias.

Após a devolutiva, mais uma revisão foi feita, desta vez por outros membros que ainda não haviam lido a entrevista. A finalidade era uniformizar as dez entrevistas entre si em termos gramaticais e de formatação, já que haviam sido feitas em momentos diferentes, por pessoas diferentes e, portanto, apresentavam características díspares. Ao final desse processo, todos membros haviam trabalhado praticamente em todas as entrevistas, o que refletiu no modo como decidimos apresentar a autoria dos textos, dividida entre quem fez a entrevista, transcrição e revisão, como os leitores e leitoras poderão ver no início de cada texto. 


\section{editorial|}

Letícia Oliver Fernandes

Matheus de Paula Silva

Pedro José de Carvalho Neto

\section{Reflexões e expectativas}

Esperamos que os leitores e leitoras possam beneficiar-se do contato com as experiências dos entrevistados e entrevistadas, acumuladas ao longo de suas trajetórias formativas e profissionais. Se, por um lado, suas falas são expressivas de vivências comuns a cada profissão, por outro, também é preciso ter o cuidado de não as tomar como a única representação possível de caminhos a serem seguidos. Foi levando isto em consideração que percebemos que o produto final cada vez mais se distanciou de um formato de um manual, para o qual talvez estivéssemos mirando inicialmente sem perceber, e se tornou um pequeno mosaico de histórias de vida de historiadores e historiadoras - histórias essas que, sozinhas, não esgotam a experiência de cada ofício, mas nos ajudam a ver o quadro mais amplo dos possíveis horizontes profissionais dos historiadores. São vislumbres de algumas das profissões possíveis, mas não de todas; são vislumbres de algumas experiências particulares no mercado de trabalho e no ambiente acadêmico.

Um elemento é comum a todas as histórias, no entanto: a passagem, seja na graduação ou na pós-graduação, dos entrevistados e entrevistadas pelo Departamento de História da Universidade de São Paulo. Todas as trajetórias aqui dispostas foram em alguma medida influenciadas, positiva ou negativamente, pelas discussões e práticas vividas dentro da instituição. Esta característica comum não foi antecipada quando da formulação do projeto; porém, atestada sua existência, parece razoável tomá-la como ponto de partida para uma possível reflexão sobre o Departamento.

Surgem as perguntas: como a instituição impacta os estudantes que por ela passam? Afinal, o quanto ela própria se deixa impactar por seus estudantes? Onde estão esses ex-alunos e alunas, o que estão fazendo, com o que estão trabalhando? 0 


\section{editorial|}

O Departamento de História da USP e as histórias que por ali caminham

que os motivou a escolher o curso e quais foram suas impressões ao entrar? Quais foram as habilidades desenvolvidas durante a graduação e para que estão sendo mobilizadas, atualmente? Sentem falta de algum aprendizado que gostariam de ter obtido durante sua formação? Se não obtiveram esse aprendizado, o que explica isso? Quais foram para a academia, quantos seguiram como arquivistas, museólogos, professores, editores, pesquisadores em outras instituiçõos? O que explica terem seguido esses caminhos? Quantos, mesmo formados, acabaram saindo da área e trabalhando em outras funções? As possibilidades de perguntas são muitas, algumas das quais aqui fizemos, outras que ainda estão por ser feitas.

Do nosso ponto de vista, olhar atentamente para as trajetórias de outros tantos ex-alunos e ex-alunas que passaram pelo Departamento pode ser uma forma de avaliar os ecos das práticas adotadas pela instituição - sejam curriculares, pedagógicas e até mesmo de pesquisa. Em um sentido mais amplo, pensamos que este movimento de escuta pode ser mobilizado como uma forma de contribuir para uma memória do Departamento de História que leve em consideração o ponto de vista do corpo discente, suas experiências e impressões individuais.

As avaliações dos entrevistados e entrevistadas sobre a passagem no Departamento são diversas entre si, como os leitores e leitoras verão; e é ao reiterarmos a singularidade de cada experiência aqui registrada que deixamos o apelo por uma expansão dessa escuta, abrindo espaço para outras vivências e efetivamente ampliando este pequeno mosaico de histórias.

Para além de sugestões de projetos futuros, o que apresentamos, ao final, é isto: um conjunto de dez entrevistas com historiadores e historiadoras com diferentes experiências profissionais e de formação.

Nunca é demais lembrar que este dossiê é fruto de um extenso trabalho coletivo, em que foram mobilizados não apenas membros da subcomissão de entrevistas, 


\section{editorial}

Letícia Oliver Fernandes

Matheus de Paula Silva

Pedro José de Carvalho Neto

mas todo o corpo editorial da Revista. A todos os membros da Revista, à professora Marlene Suano, aos entrevistados e às entrevistadas, aos leitores e às leitoras: nossos mais sinceros agradecimentos por nos acompanharem até aqui.

Desejamos uma boa leitura! 